\title{
PENGUATAN KAPASITAS EKONOMI PONDOK PESANTREN NURUL JADID MELALUI UNIT USAHA EN-JE MART
}

\author{
Agus Sulthoni Imami \\ Universitas Nurul Jadid Probolinggo, Indonesia \\ djdjenar@gmail.com \\ Halimi Fauzen \\ Universitas Nurul Jadid Probolinggo, Indonesia \\ halimifauzan561@gmail.com \\ Muhammad Mukhles \\ Universitas Nurul Jadid Probolinggo, Indonesia \\ mukhlisriddick3@gmail.com
}

\begin{abstract}
Strengthening capacity is a demand for policies that will be taken in the process of improvement or change for individuals or institutions in achieving predetermined goals. Strengthening the capacity in the business will have a significant impact on the sustainability of the business being carried out. Nurul Jadid Islamic boarding school is one of the Islamic boarding schools which has significant influence on many aspects of community life. The existence of a pesantren business, namely EN-JE mart, is one of the income-generating business units for the pesantren. The results of the study obtained from this study include the strategies used by EN-JE mart to attract consumers, both in
\end{abstract}


terms of improving the organizational structure, budget capacity, facilities and infrastructure, and services. By using descriptive qualitative research methods, the description obtained from the results of this study aims to provide insight and further assess the positive performance of ENJE mart.

Keywords: capacity strengthening, Islamic boarding school business unit

\section{Pendahuluan}

Pada umumnya, awal keberadaan pondok pesantren merupakan tempat belajar mengajar khususnya bagi umat Islam secara mendalam. Pondok pesantren merupakan sebuah lembaga pendidikan tradisional Islam yang di dalam terdapat siswa atau santri yang menetap dalam salah satu tempat (asrama) tujuannya untuk memahami, menghayati, dan mengamalkan ajaran Islam dengan menekankan pentingnya ajaran agama Islam sebagai pedoman hidup bermasyarakat. ${ }^{1}$ Seiring dengan berlanjunya zaman dengan perkembangan kajian keilmuan, pesantren mulai dikaji dalam berbagai aspek lainnya. Seperti sistem pembelajaran modern berbasis ilmu kepesantrenan, ideologi yang dimiliki pesantren, sampai pengelolaan manajemen perekonomian pesantren.

Peran pesantren dalam menonggak aspek kehidupan ekonomi tidak perlu diragukan lagi. Mengingat jumlah penduduk Indonesia yang mencapai 271, 34 juta jiwa membuat beban Indonesia semakin berat. Laju pertumbuhan penduduk yang begitu tinggi memberi dampak luas bagi penyediaan pangan, pendidikan, kesejahteraan, dan lapangan kerja. Pesantren memiliki potensi untuk berkembangnya usaha mikro di negeri ini. Anggaran Rp 20 triliun lewat kredit usaha rakyat (KUR) harus menyertakan pesantren dalam membangun fondasi perekonomian nasional. Mengikutsertakan pesantren dalam pengelolaan usaha mikro, kecil, dan menengah, dapat meringankan beban perekonomian bangsa ke depan. ${ }^{2} \mathrm{Hal}$ ini disebabkan lantaran lokasi pesantren rata-rata berada ditengah-tengah wilayah masyarakat, sehingga sangat memungkinkan bila keberadaan pesantren memiliki peran yang sangat berpengaruh terhadap pola kehidupan masyarakat sekitar terlebih dalam hal ekonomi.

Undang-undang Nomor 18 Tahun 2019 tentang Pesantren, disebutkan bahwa pesantren memiliki posisi strategis, yakni sebagai lembaga pendidikan, lembaga dakwah, sekaligus lembaga pemberdayaan

\footnotetext{
${ }^{1}$ Hasbullah, Kapita Selekta Pendidikan Islam (Jakarta: Grafindo Persada, 1996 ), 49.

2 Made Saihu, Manajemen Berbasis Sekolah, Madrasah, dan Pesantren, (Tanggerang: Yapin An-Namiyah, 2020), hlm. 171.
} 
masyarakat. Sebagai lembaga Pendidikan Islam tertua di Indonesia, pesantren memiliki potensi serta peran dalam membangun perekonomian bangsa Indonesia. Sebagaimana Abd Mu'in dalam bukunya berjudul "Pesantren dan Pengembangan Ekonomi Umat", bahwa beberapa ahli sosiologi seperti Greetz, Castle, Kuntowijoyo, De jongge, dan Muhaimin, sepakat bahwa etika agama mampu menjadi pendorong munculya transformasi ekonomi diberbagai tempat. ${ }^{3}$

Pesantren di era globalisasi ini, adalah pesantren yang mampu memodifikasi antara kebutuhan masyarakat dengan tujuan pesantren sebagai lembaga pembinaan dan pemberdayaan ummat. Pendidikan pesantren dituntut mengembangkan life skill dan leadership skill education. ${ }^{4}$ Sehingga banyak langkah yang dilakukan oleh lembaga pesantren untuk meningkatkan integritas perkembangan pesantren ke arah yang lebih maju.

Adanya IPTEK (Ilmu Pengetahuan dan Teknologi) yang terus berkembang saat ini, membuat perubahan tersendiri dalam struktur perekonomian pesantren. Seperti pada pesantren Nurul Jadid yang merupakan lokasi penelitian ini dilakukan. Pesantren ini mulai mengibarkan sayapnya dalam meningkatkan kemandirian ekonomi ke arah yang lebih modern dengan memanfaatkan ilmu pengetahuan dan teknologi yang ada. Penguatan kapasitas yang dikembangkan ini memiliki tujuan sebagai proses peningkatan atau perubahan dalam sistem kelembagaan pesantren yang lebih terstruktur, efisien dan berkembang maju mengikuti perkembangan masa.

Jenis-jenis usaha ekonomi yang dapat dikembangkan pada pesantren umumnya dapat diklafikasikan ke dalam 4 kelompok besar yaitu: Agribisnis (pertanian, peternakan, perikanan, perkebunan); jasa (percetakan, laziz, Koperasi; Perdagangan (Ritel, pertokoan, agen penjualan), serta industri (penjernihan air, meubeler). Sebagaimana dilansir dari laman resmi pondok pesantren Nurul Jadid, pondok pesantren ini mengelola banyak usaha yang dikembangkan sebagai penunjang perekonomian. Seperti NJ Print, NJ Mart, UD Mandiri, UD Sinar Sejahtera, Enje Enterprise, dan Pustaka Nurja. Fokus penelitian ini mengarah pada usaha ritel yang dikelola oleh pondok pesantren Nurul Jadid yaitu toko bidang usaha EN-JE Mart. Usaha ini telah didirikan pada 12 Juli 2020 silam. Menyediakan berbagai macam kebutuhan sehari-

\footnotetext{
${ }^{3}$ Ishomuddin, dkk, Pembangunan Sosial Dalam Menghadapi Masyarakat Ekonomi Asean, (Pamekasan: Duta media Publishing, 2016), hlm. 292.

${ }^{4}$ Khoirur rozaq, "Tantangan Pesantren dalam Menghadapi Asean Economic Community" Tebuireng, Edisi 43, Maret-April 2016, hlm. 14.
} 
hari seperti sembako, makanan ringan, dan kebutuhan rumah tangga lainnya, sekaligus melayani simpanan bekal santri.

Keberadaan EN-JE Mart sebagai salah satu penyumbang pendapatan pesantren, membuat kami tertarik mengangkatnya ke dalam proses penelitian. Fokus yang akan dituju ialah mengenai prosedur aspek kerja yang digunakan, sistem manajemen, sekaligus strategi yang digunakan EN-JE Mart dalam mengembangkan usaha. Sejatinya, EN-JE Mart memang sama seperti toko ritel lainnya dalam hal produk penjualan dan sistem pembayaran. Namun perbedaan mencoloknya ialah karena toko ini dikelola dan didirikan langsung dalam ruang lingkup pondok pesantren. Sehingga dari segi pelayanan, manajemen, maupun proses transaksi nya sangat mengedepankan nilai-nilai keIslaman. Hal ini menjadi sangat menarik jika dikaji lebih jauh untuk mengetahui keunggulan yang ditawarkan serta melihat peran yang diberikan EN-JE mart terhadap pondok pesantren Nurul Jadid.

Dari pemaparan latar belakang diatas, dapat diambil rumusan masalah sebagai berikut: 1) Apa strategi yang digunakan unit usaha ENJE Mart untuk mengembangkan usaha? 2) Bagaimana penguatan kapasitas unit usaha EN-JE Mart dalam melaksanakan fungsinya sebagai salah satu unit penyumbang pendapatan bagi pesantren? 3) Apa saja faktor penghambat dan pendukung yang dihadapi oleh unit usaha EN-JE Mart dalam menjalankan sistem pengelolaannya?

Tujuan dari adanya penelitian ini ialah Mampu memberikan penjelasan mengenai adanya strategi usaha, sekaligus keunggulan maupun hambatan yang dihadapi oleh EN-JE Mart dalam mengembangkan kapasitas perekonomian pesantren melalui usaha ritel.

\section{Kerangka Teoritik \\ Penguatan Kapasitas}

Penguatan adalah suatu proses upaya yang sistematis menjadikan lembaga suatu masyarakat menjadi lebih baik, dinamis, berdaya dan kuat dalam menghadapi berbagai pemenuhan kebutuhan dan tantangan atau hambatan yang dapat mempengaruhi eksistensinya. ${ }^{5}$ Kapasitas berasal dari bahasa Belanda; capacitiet yang berarti tiga hal pertama yakni daya tampung atau daya serap, kedua ruang atau fasilitas yang tersedia, dan terakhir kemampuan maksimal. ${ }^{6}$ Kapasitas merupakan sebuah kemampuan personal yang melekat pada diri seseorang, organisasi atau

\footnotetext{
${ }^{5}$ Yuli Kurniati, Penguatan Kapasitas Kelembagaan Kelompok PEW Untuk Pengembangan Ekonomi Lokal Kota Yogyakarta, Jurnal Maksipreneur, Vol. III, No. 1, hal 90-120. ${ }^{6}$ Hadfield, M., Chapman, C., Curryer, I., \& Barrett, P. (2004). Building Capacity Developing Your School. Retrieved from http:// www.ncsl.org.uk (Akses 19 Februari 2021).
} 
sistem dalam menjalankan fungsi sebagaimana mestinya untuk mencapai tujuan yang lebih efisien.

Dalam pengertian yang lebih luas, kapasitas tidak hanya berkaitan dengan keterampilan dan kemampuan individu, tetapi juga dengan kemampuan organisasi untuk mencapai misinya secara efektif dan kemampuan mempertahankan kelangsungan hidupnya dalam jangka panjang. ${ }^{8}$ Sedangkan United Nation Development Program (UNDP) mendefinisikan kapasitas sebagai kemampuan (kemampuan memecahkan masalah) yang dimiliki seseorang, organisasi, lembaga, dan masyarakat untuk secara perorangan atau secara kolektif melaksanakan fungsi, memecahkan masalah, serta menetapkan dan mencapai tujuan. ${ }^{9}$

Penguatan kapasitas merupakan suatu proses peningkatan atau perubahan perilaku individu, organisasi dan sistem masyarakat dalam mencapai tujuan yang telah ditentukan secara efektif dan efisien. Dalam pengertian tersebut, terkandung pemahaman bahwa: 1.) Kapasitas adalah kemampuan (individu, kelompok, organisasi dan kelembagaan yang lain) untuk menunjukkan dan memerankan fungsinya secara efektif, efisien, dan berkelanjutan. 2.) Kapasitas bukanlah sesuatu yang pasif, melainkan proses yang berkelanjutan. 3.) Pengembangan kapastitas sumber daya manusia merupakan pusat pengembangan kapasitas. 4.) Yang dimaksud dengan kelembagaan, tidak terbatas dalam arti sempit (kelompok, perkumpulan, atau organisasi), tetapi juga dalam arti luas, menyangkut perilaku, nilai-nilai dll.

Merujuk pendapat Sumpeno, penguatan kapasitas berarti terjadi perubahan perilaku untuk: 1). Meningkatkan kemampuan individu dalam pengetahuan, keterampilan dan sikap; 2). Meningkatkan kemampuan kelembagaan dalam organisasi dan manajemen, keuangan dan budaya; 3). Meningkatkan kemampuan masyarakat dalam kemandirian, keswadayaan dan mengantisipasi perubahan. Hasil yang diharapkan dengan adanya penguatan kapasitas menurut Sumpeno adalah: 1). Penguatan individu, organisasi dan masyarakat. 2). Terbentuknya model pengembangan kapasitas dan program 3). Terbangunnya sinergisitas pelaku dan kelembagaan. ${ }^{10}$

\footnotetext{
7 Anneli Milen, Pegangan Dasar Pengembangan Kapasitas, (Yogyakarta: Pembaharuan, 2004), hlm. 12.

8 Amiruddin Idris, Pengantar Ekonomi Sumber Daya Manusia, (Yogyakarta: deepublish, 2016), hlm. 74.

${ }_{9}$ Nunuk Indarti, Pemberdayaan Industri Kecil dan Menengah Melalui Capacity Building pada Industri Mebel di Kota Pasuruan, (Surabaya: Lembaga Academic \& Research Institute, 2020), hlm. 27.

${ }^{10}$ Yuli Kurniati, et. al.
} 
Penguatan kapasitas untuk menumbuhkan partisipasi masyarakat tersebut, mencakup penguatan kapasitas setiap individu (warga masyarakat), kapasitas kelembagaan (organisasi dan nilai perilaku), dan kapasitas jejaring (networking) dengan lembaga lain dan interaksi dengan sistem yang lebih luas. Disuatu pihak, penguatan diarahkan untuk melebih-mampukan individu agar lebih mampu berperan didalam kelompok dan maysrarakat global, ditengah-tengah ancaman yang dihadapi baik dalam kehidupan pribadi, kelompok dan masyarakat global. $^{11}$

\section{Unit Usaha Pondok Pesantren}

Usaha dalam dunia ekonomi seringkali diartikan sebagai bisnis. Dalam hal ini, usaha dilakukan dengan tujuan untuk mendapatkan keuntungan. Sebagaimana yang dikemukakan Nana Supriatna dkk, "usaha merupakan aktivitas atau kegiatan ekonomi yang dilaksanakan oleh manusia dalam rangka mencapai tujuan yang telah ditetapkan sebelumnya". ${ }^{12}$

Sedangkan pelaku usaha merupakan orang atau lembaga yang berbentuk badan hukum maupun bukan badan hukum yang didirikan dan berkedudukan atau melakukan kegiatan dalam wilayah hukum negara Republik Indonesia, baik sendiri maupun bersama-sama melalui perjanjian menyelenggarakan kegiatan usaha dalam berbagai bidang ekonomi. ${ }^{13}$

Ruang lingkup pendirian usaha sangat beragam, baik usaha dagang maupun usaha jasa. Usaha bisa didirikan oleh kalangan orang yang sudah berkecimpung dalam dunia usaha sebelumnya, maupun orang yang baru mulai mengenal dunia usaha. Usaha juga bisa didirikan oleh satuan lembaga yang menjadikan usaha sebagai salah satu penguat sumber perekonomiannya.

Pesantren sebagai lembaga paling berpengaruh terhadap perekonomian sekitar maupun daerah, adanya usaha-usaha yang didirikan menjadi salah satu bentuk komitmen pesantren sebagai media pembelajaran, baik dalam pendidikan agama maupun sebagai contoh terhadap perkembangan ekonomi berbasis teori dan praktik sesuai ajaran Islam. Unit usaha merupakan sub-sub dari berbagai jenis usaha yang didirikan pesantren. Unit usaha ini dikelola langsung oleh pesantren

11 Agus affandi, Dasar-Dasar Pengembangan Masyarakat Islam, (Surabaya: IAIN Sunan Ampel Press, 2013), hal. 151

${ }^{12}$ Edi Sofwan, Hukum Bisnis dan Regulasi, (Banten: Desanta Muliavisitama, 2020), hlm. 51.

13 Elsi Kartika Sari dan Advendi Simanunsong, Hukum Dalam Ekonomi, Jakarta: Grasindo, 2007), hlm. 159 
melalui skill yang dimiliki oleh para santri maupun dari pihak luar yang mempunyai jiwa wirausaha sesuai ajaran syariah.

Kemandirian pesantren dapat terwujud dengan manajemen sumber daya pesantren yang terdiri proses dan tahapan sebagai berikut:

1. Tahap perencanaan yang terjadi diawali dengan perencanaan itu sendiri, pelaksanaan dan monitoring (evaluasi).

2. Model yang diterapkan adalah model "open management" yang diaplikasikan lewat proses perencanaan, penyusunan kegiatan, serta penganggaran terhadap pembiayaan yang dibutuhkan.

3. Sumber-sumber dananya meliputi dana dari pemerintah (World Bank), masyarakat (syariah santri), unit usaha wartel, koperasi, kantin, dan unit usaha mebel (furnitur).

4. Strategi yang diterapkan adalah planning dan thinking strategy.

5. Implikasi efektifitas manajemen sumber dana bagi perkembangan pondok adalah:

a.) Efektifitas manajemen sumber dana yang terjadi berpengaruh pada bertambahnya lembaga pendidikan Islam yang dinaunginya.

b.) Faktor pendukung dari pada manajemen adalah terletak pada baiknya relasi terjadi hubungan baik semua pihak baik internal maupun eksternal.

c.) Alternatif pemecahan masalah (problem solving) yang dilakukan adalah profesionalisasi tenaga kependidikan terkait yang ada serta rekrutmen tenaga yang kompeten (profesional).

Sementara itu, prinsip-prisip dalam membangun unit usaha di pesantren adalah (1) unit usaha bukan milik pribadi akan tetapi milik lembaga, pimpinan tidak berhak mengambil kebijakan sektoral terkait pengelolaan keuangan; (2) berfilosofikan administrasi yang baik mutlak untuk menjaga kepercayaan, harus ada laporan dan musyawarah rutin ked an oleh pimpinan terkait perkembangan unit usaha; (3) merekrut SDM yang memang ahli lapangan dan berasal dari internal lembaga sehingga komunikasi dapat berjalan lancar; (4) memperhatikan legalitas badan usaha untuk mengoptimalkan peluang yang ada; (5) membentuk tim ahli, minimal tenaga senior untuk memonitor perkembangan unit usaha.

Dalam sebuah unit usaha pesantren terdapat dua peranan yang berbeda dalam sebuah organisasi. Pertama, disebut peran kepemimpinan yaitu mengerjakan hal yang benar, ini berhubungan dengan visi dan arah. Kedua, disebut peranan manajemen yaitu mengerjakan hal secara benar, atau pelaksanaan. Dalam sebuah unit usaha bagaimana kita bisa 
memanage dalam hal mencangkup empat fungsi lazim dalam manajemen yaitu kepemimpinan, pengorganisasian, pelaksanaan dan evaluasi.

Dalam sebuah pedoman yang terdapat dalam akutansi pesantren memiliki dua jenis usaha yang berada di pondok pesantren. 1). Pondok pesantren memiliki berbagai macam unit usaha yang di bangun secara mandiri baik dalam segi pengelolaannya, manajemennya dll, yang mengikuti koridor hukum yang di tetapkan oleh pesantren. 2). Unit usaha yang berada di pondok pesantren juga dapat mendirikan berbagai unit usaha sebagai badan hukum yang terpisah, seperti halnya dalam lembaga keuangan seperti koperasi, perseroan terbatas, dan bentuk hukum yang lainnya. Unit usaha yang kedua tidak termasuk dalam sebuah entitas pelaporan dalam sebuah pondok pesantren. Jadi jenis unit usaha ini memiliki ciri yang bisa jadi melibatkan pihak luar baik dalam hal kepemilikannya maupun dari sumber modal yang dikelolanya. Dalam sebuah unit usaha sejenis ini pemilik atau pengguna wajib untuk melaporkan terhadap progres dalam kinerjanya.

\section{Metodologi Penelitian}

Dalam penulisan penelitian ini, menggunakan metode penelitian lapangan (field research) dengan pendekatan kualitatif deskriptif. Yang mana, penelitian kualitatif merupakan suatu penelitian yang hasil penelitiannya tidak diperoleh melalui prosedur statistik atau metode kuantifikasi yang lain, namun dengan menggunakan pendekatan naturalistik untuk memahami suatu fenomena tertentu. ${ }^{14}$ Penelitian kualitatif deskriptif yaitu penelitian yang menekankan pada penjelasan berbentuk uraian serta menggambarkan kondisi apa adanya. Penelitian ini dibuat atas dasar perkembangan unit usaha pondok pesantren Nurul Jadid yaitu unit usaha EN-JE mart yang keberadaannya memberikan dampak yang positif terhadap perkembangan pondok pesantren baik dari segi manajemen maupun citra yang baik bagi masyarakat. Adapun penjelasan lengkapnya, sebagaimana dibawah ini:

\section{Objek Penelitian}

Objek penelitian disini adalah unit usaha EN-JE Mart yang terletak di Kawasan Pondok Pesantren Nurul Jadid, jalan KH Zaini Mun'im, Dusun Tanjung Lor, Karanganyar, Kec Paiton, Kab Probolinggo. Toko ini menyediakan berbagai kebutuhan sehari-hari seperti pangan rumah tangga dan menjadi salah satu bentuk penunjang perekonomian di pesantren Nurul Jadid.

\footnotetext{
${ }_{14}$ Albi Anggito dan Johan Setiawan, Metodologi Penelitian Kualitatif, (Sukabumi: Jejak Publisher, 2018), hlm. 9.
} 


\section{Metode Pengumpulan Data}

Observasi

Observasi berarti kegiatan pengamatan dan mengumpulkan data langsung dari lapangan. Metode ini digunakan untuk memperoleh data terhadap penguatan kapasitas perekonomian pesantren dan pengelolaan sistem pelayanan unit usaha EN-JE Mart dalam mengembangkan usahanya. Serta melihat peran pesantren dan respon masyarakat sekitar dalam keberlangsungan usaha ini melalui pengamatan langsung di lapangan.

Studi Pustaka

Studi Pustaka adalah suatu karangan ilmiah yang berisi pendapat berbagai pakar mengenai suatu masalah, yang kemudian ditelaah dan dibandingkan dan ditarik kesimpulannya. ${ }^{15}$ Selain observasi, penelitian ini juga menggunakan teknik pengumpulan data kepustakaan atau library research yang mengukit dari berbagai sumber seperti buku maupun jurnal yang terkait dengan penjelasan didalam penelitian ini.

Metode interview

Interview (wawancara) adalah metode pengumpulan data atau mendapatkan informasi dengan cara bertanya langsung kepada responden. ${ }^{16}$ Dalam hal ini, penelitian menggunakan sistem Opened and controlled, artinya antara peneliti dan interviewer lebih bebas dalam pembicaraan. Hal ini juga ditujukan agar komunikasi antara peneliti dan pihak yang di interview lebih komunikatif dan terarah. Narasumber akan dipilih langsung dari pengelola unit usaha serta badan yang berkaitan dengan struktur personalia EN-JE Mart.

Metode analisis data

Dalam hal ini, peneliti menggunakan metode analisis data kualitatif dalam menganalisis data yang diperoleh. Dengan menggunakan metode ini, peneliti menjelaskan data-data yang diperoleh melalui pemaparan deskriptif. Artinya tidak menggunakan angka-angka sebagaimana penelitian kuantitatif, namun menggunakan pernyataan-pernyataan dan keterangan yang terdeskripsi.

\section{Pembahasan}

\section{Identifikasi Penguatan Kapasitas Unit Usaha EN-JE Mart}

Membangun perekonomian pesantren tentu tidak terlepas dari usaha-usaha yang dikelola sebagai penunjang utama perekonomian. Awal

\footnotetext{
${ }^{15}$ Haryanto A.G, dkk, Metode Penulisan dan Penyajian Karya Ilmiab: Buku Ajar Untuk Mahasiswa, (Jakarta: EGC, 2000), hlm. 78.

${ }^{16}$ Wahyu Hidayat Riyanto dan Achmad Mohyi, Metodologi Penelitian Ekonomi, (Malang: UMMPress, 2020), hlm. 82.
} 
mulanya, pesantren Nurul Jadid hanya menyediakan toko kecil berbasis koperasi pesantren sebagai media untuk mencukupi kebutuhan santri. Koperasi tersebut memberikan hampir semua perlengkapan hidup santri. Namun seiring perkembangan masa yang modern, pesantren mulai membuat inovasi baru dengan mendirikan toko ritel yang menjual lebih banyak kebutuhan santri bahkan masyarakat. Sekaligus sebagai salah satu bentuk pendekatan kepada masyarakat maupun sebagai elemen tonggak perekonomian pesantren. Namun standart tersebut harus tetap berpegang teguh terhadap nilai-nilai syariah.

EN-JE mart adalah salah satu unit usaha yang memiliki banyak keunggulan dari beberapa aspek bisnis yang dikelola pesantren. Dalam menjalankan perannya sebagai wadah jihad ekonomi, ada beberapa aspek yang menjadi peranan penting pesantren untuk perkembangan usaha EN-JE mart, diantaranya:

\section{Struktur Organisasi}

Efektivitas sistem kepemimpinan dan sistem perencanaan strategis sebagian bergantung pada struktur organisasi kejelasan wewenang, tanggung jawab, jalur pelaporan, dan standar kinerja antara beragam individu disetiap tingkatan organisasi. ${ }^{17}$ Menurut Millen, teori dimensi organisasi dalam pengembangan kapasitas ialah bahwa salah satu penataan organisasi memfokuskan pada proses dan struktur organisasi yang dapat mempengaruhi bagaimana organisasi tersebut menetapkan tujuannya dan menyusun pekerjaannya secara intensif. Jadi dalam kelembagaan perlu adanya struktur organisasi yang memadai. ${ }^{18}$

Dalam struktur organisasi EN-JE mart, pelaksanaan tugas ditetapkan oleh pihak manajer sesuai dengan integritas karyawan masingmasing. Adanya struktur organisasi ini yaitu dalam rangka menunjang operasional toko. Para karyawan beserta tim dari setiap devisi mempunyai tanggung jawab untuk mengatur dan mengelola sistem keberlanjutan prospek kerja kedepan.

Dalam hal perekrutan karyawan baru, pihak pengelola EN-JE mart tidak menekankan bahwa calon karyawan harus dari kalangan santri, yang utama adalah integritas yang dimiliki dan mampu bekerja dengan baik yang sesuai peraturan konsep toko serta menjunjung tinggi syariah Islam.

\footnotetext{
${ }^{17}$ James R. Evans dan William M. Lindsay, Pengantar Six Sigma An Introduction to Six Sigma \& Process Improvement, (Jakarta: Salemba Empat, 2007), hlm. 367.

18 Ardie Pratama, Muchammad Mustam, Titik Djumiarti, "Pengembangan Kapasitas Kelembagaan Dalam Koordinasi Pelayanan Perizinan Di BPPT Kota Semarang”. Journal of Public Policy and Management Review. Vol 3 Nomor 1, Tahun 2013, hlm. 7.
} 


\section{Strategi Pengelolaan Toko}

Setiap bisnis pasti mempunyai strategi khusus dalam menjalankan usahanya. Strategi adalah suatu model dimana pimpinan atau manajer menentukan arah jangka panjang, dalam soal kinerja atau prestasi lembaga/organisasi melalui formulasi yang cermat, implementasi yang tepat, dan evaluasi terus menerus dengan strategi yang telah ditetapkan. ${ }^{19}$ Strategi yang didapatkan bisa berasal dari beragam keadaan, seperti sumber pemikiran yang dihasilkan melalui saran konsumen, inspirasi yang berasal dari supplier dan kompetitor, maupun sumber ide dari pemikiran para pengelola bisnis sendiri berdasarkan kesepekatan bersama. Strategi tersebut nantinya akan digunakan untuk membangun citra bisnis yang lebih kooperatif dengan pelanggan dalam hal mendapatkan tempat baru di pasaran. Ada beberapa strategi yang diterapkan EN-JE mart guna meningkatkan kualitas pengelolaan toko, diantaranya:

\section{Strategi Pemasaran}

Kotler dan Keller mengemukakan inti dari pemasaran adalah memuaskan kebutuhan dan keinginan konsumen. Sasaran dari bisnis adalah mengantarkan nilai pelanggan untuk menghasilkan keuntungan (laba/profit). ${ }^{20}$ Strategi yang digunakan EN-JE mart dalam hal menarik konsumen ialah dengan menekan harga jual yang ekonomis agar tetap bisa bersaing dengan kompetitor lain yang sudah ada sebelumnya, serta menjalin komunikasi yang baik terhadap masyarakat, dengan harapan memberikan kenyamanan dan kemudahan dalam bertransaksi dan berbelanja. Pemberian voucher belanja ataupun giveway masih belum diprioritaskan, sebab masa operasional toko ini masih belum cukup lama untuk memberikan doorprise untuk pelanggan. Namun, pelayanan dan harga yang kompetitif adalah kunci utama dalam menarik konsumen.

Terdapat dua jenis sistem pemasaran dalam pengelolaan toko ENJE mart, yaitu sistem grosiran atau logistik serta sistem ecer. Dalam hal ini EN-JE mart berperan sebagai pasar yang monoton, sedang logistik mengkondisinir toko-toko atau koperasi dalam pesantren. Sistem grosiran atau logistik dalam pengelolaannya tidak terlalu sulit untuk dijalankan, mengingat hanya EN-JE mart yang saat ini menjadi pemasok utama dalam koperasi pesantren. Sedang sistem ecer dikelola seperti toko ritel lainnya, yaitu pembeli bebas memilih barang yang dibutuhkan di tempat yang sudah disediakan berdasarkan tempat kriteria barang yang dimodifikasi sedemikian rupa untuk memudahkan pelanggan.

\footnotetext{
${ }^{19}$ A. Halim, dkk, Manajemen Pesantren, (Yogyakarta: Pustaka Pesantren, 2005), hlm. 15.

${ }^{20}$ Muhammad Yusuf Saleh dan Milah Said, Konsep dan Strategi Pemasaran, (Makassar: CV Sah Media, 2019), hlm. 2.
} 
Selain itu, EN-JE mart juga menyediakan sistem belanja online melalui e-commerce. Sehingga mudah untuk dijangkau oleh masyarakat luas dan bisa di akses kapanpun dan dimanapun tanpa perlu ke datang toko langsung. Sistem pembayaran yang tersedia bisa melalui cash, kartu debet/kredit, serta e-payment dengan menggunakan kartu e-bekal bagi para santri, alumni dan wali santri.

\section{Keunggulan Sarana dan Prasarana}

Pengembangan bisnis di era modern banyak memanfaatkan faktor pendukung dalam beragam aksi untuk melebarkan misi bisnisnya. Sistem pelayanan, kecepatan respon, maupun desain ruangan yang menarik, akan membawa dampak positif kepada masyarakat atau pelanggan yang merasakan kenyamanan tersebut. Sehingga kemungkinan mempunyai pelanggan tetap akan lebih besar. Bahkan tak jarang jika berita baik tersebut akan disalurkan kepada pelanggan lain. Artinya, pesan yang kredibel tersebut akan cepat mendongkrak awereness, ekuitas, dan image sebuah brand menuju singgasana tertinggi, dalam kata lain; bisnis akan semakin maju dengan dikenal banyak kalangan.

Sarana dan prasarana yang dimiliki EN-JE mart seperti adanya komputer sebagai media operasional mengelola data maupun tempat untuk menjalankan usaha berbasis online. Sarana lain yang juga sangat berpengaruh terhadap citra toko seperti tersedianya AC, lampu, CCTV, ATM, motor sebagai media untuk pengantaran barang, beserta peran pendukung lainnya. Dalam hal ini akan memberikan suatu dampak yang sangat signifikan dalam hal menjalankan suatu peran toko dalam mengembangkan pertokoan nya dengan tujuan untuk memberikan pelayanan yang baik dan optimal kepada konsumen.

\section{Kapasitas Anggaran}

Dalam kapasitasnya sebagai salah satu fungsi manajemen, tahap monitoring membawa pada merupakan langkah akhir yang akan sebuah siklus yang berputar. ${ }^{21}$ Adanya sistem manajemen yang baik, akan membawa pengaruh yang bagus terhadap keputusan dan nasib masa depan usaha.

Dalam membangun usaha, modal menjadi faktor utama untuk merealitakan anggaran yang direncankan. Pada awal mula rencana pembuatan toko ritel EN-JE mart, bidang usaha bermodal uang sebesar 20 juta rupiah sebagai modal awal membeli perlengkapan isi toko. Dengan seiring berjalannya waktu, perkembangan yang diperoleh cukup

\footnotetext{
${ }^{21}$ Aries Heru Prasetyo, Sukses Mengelola Keuangan Usaha Mikro Kecil Menengah, (Jakarta: PT Elex Media Komputindo, 2010), hlm. 88.
} 
membuahkan hasil yang positif. Hingga saat ini pendapatan EN-JE mart dalam mengelola usaha ini berkisar 600 juta rupiah dengan laba bersih sekitar 20 juta rupiah. Hal ini diperkirakan akan terus mengalami kenaikan hingga 1\% perbulan. Anggaran tersebut yang nantinya akan memutuskan arah usaha ini akan terus berjalan atau dihentikan. Pasalnya, EN-JE yang tidak memiliki anggaran usaha dalam operasional usahanya, menggunakan anggaran yang didapat melalui laba usaha yang diperoleh dalam periode waktu awal buka hingga sekarang.

\section{Faktor Pendorong dan Penghambat Yang Dihadapi EN-JE mart Dalam Pengoperasian Usaha}

Faktor pendukung dan penghambat dalam suatu usaha adalah salah satu faktor penentu atas perkembangan dan kemajuan usaha. Adanya kedua faktor tersebut memberikan timbal balik yang cukup relevan bagi komunitas kinerja. Terdapat banyak faktor pendukung dalam pengoperasian usaha, salah satunya seperti dukungan yang ditawarkan oleh berbagai pihak baik berupa materi maupun non materi. Begitupun faktor penghambat yang mungkin menerjang karir suatu usaha seperti adanya operasional manajemen yang kurang stabil, SDM yang minim, maupun kerjasama struktural yang masif pasif.

Kelemahan yang sering menjadi faktor penghambat dan permasalahan dari usaha mikro terdiri dari 2 faktor, yaitu:

1. Faktor internal
a. Masih terbatasnya kemampuan sumber daya manusia
b. Kendala pemasaran produk khususnya dalam informasi pasar dan jaringan
c. Adanya kecenderungan konsumen yang belum mempercayai mutu produk dari industri kecil
d. Kendala permodalan usaha karena sebagian besar industri kecil memanfaatkan modal sendiri dalam jumlah yang relatif kecil.

\section{Faktor eksternal}

Faktor eksternal merupakan masalah yang biasanya muncul dari pihak pengembang dan pembina usaha. Misalnya, solusi yang diberikan tidak tepat sasaran, tidak adanya monitoring dan program yang saling tumpang tindih. ${ }^{22}$

Sumber daya manusia adalah salah satu faktor yang cukup kuat bagi keberlanjutan usaha EN-JE mart dalam memaksimalkan kinerja. Hal tersebut sekaligus menjadi faktor pendukung dan penghambat atas

\footnotetext{
22 Devi Wahyuni, KKN-DR, Sebuah Usaha Pemberdayaan Masyarakat Ditengah Pandemi Covid-19, Kearsipan Pusat Pengabdian Kepada Masyarakat Universitas Islam Negeri Sunan Gunung Djati Bandung, 2020, hlm. 182.
} 
strategi kemajuan toko. SDM yang kompeten dan arah manajemen yang baik akan membawa citra toko ini meraih misi yang diharapkan.

Adanya sumber daya manusia merupakan faktor sentral utama pada sebuah bisnis. SDM menjadi tonggak utama perkembangan usaha dalam mewujudkan visi dan misinya. Sebagaimana yang ditegaskan Simamora bahwa manusia adalah sumber daya yang amat penting dan menentukan, baik dalam organisasi pemerintahan maupun swasta karena SDM adalah perencana, pelaku dan berperan aktif dalam aktivitas organisasi. SDM juga membuat sumber daya lain bekerja dan berfungsi.

Sumber daya manusia yang handal diharapkan akan mampu memberikan kontribusi yang baik terhadap langkah yang akan diambil EN-JE mart untuk masa depan. Sumber daya manusia tersebut yang nantinya akan menentukan karir EN-JE mart menghadapi pengaruh pasar yang ketat dalam persaingan bisnis.

\section{Kesimpulan}

Penguatan kapasitas yang dilakukan EN-JE mart cukup baik untuk menambah citra pondok pesantren yang positif. Nurul Jadid sebagai salah satu pesantren yang memiliki peran penting dalam kehidupan masyarakat, tidak hanya menyediakan pembelajaran agama bagi para santri, namun disertai skill wirausaha sebagai media praktek dalam hal ekonomi dengan disandarkan terhadap landasan syariah.

Usaha yang dilakukan untuk memaksimalkan perkembangan perekonomian, mampu memberikan nilai dan pandangan yang baik dihati masyarakat. Berdirinya beberapa usaha dalam rung lingkup pesantren seperti adanya EN-JE mart sebagai toko ritel, dengan strategi yang digunakannya mampu memberikan aspek yang luar biasa terhadap minat masyarakat dalam berbelanja kebutuhan. Kontribusi yang dilakukan oleh pihak pengelola maupun pengurus bidang usaha, turut menyongsong EN-JE mart menjadi salah satu unit usaha yang menyumbang pendapatan pesantren.

Meski adanya EN-JE mart sudah cukup diterima dengan baik oleh banyak kalangan, namun ada beberapa dimensi yang mungkin perlu di tegaskan lagi untuk diperbaiki. Salah satunya ialah dari segi SDM, yang mana SDM ini yang nantinya akan mampu menjadi tolak ukur utama terhadap kemajuan toko EN-JE mart. SDM yang baik, kesempatan toko menjadi lebih maju juga akan besar. Pasalnya, SDM juga menjadi faktor penghambat terhadap berjalannya toko. Kekurangan SDM yang mumpuni dalam bidangnya, akan berdampak terhadap keberlanjutan usaha ini kedepan. Untuk itu, para pengelola akan terus melakukan perbaikan maupun pelatihan terhadap SDM yang lebih unggul. 


\section{Daftar Pustaka}

A.G, Haryanto, dkk. 2000. Metode Penulisan dan Penyajian Karya Ilmiah: Buku Ajar Untuk. Mahasiswa. Jakarta: EGC.

Affandi, Agus. 2013. Dasar-Dasar Pengembangan Masyarakat Islam, Surabaya: IAIN Sunan Ampel Press.

Anggito, Albi, Johan Setiawan. 2018. Metodologi Penelitian Kualitatif. Sukabumi: Jejak Publisher.

Ardie Pratama, Muchammad Mustam, Titik Djumiarti. 2013. "Pengembangan Kapasitas Kelembagaan Dalam Koordinasi Pelayanan Perizinan Di BPPT Kota Semarang". Journal of Public Policy and Management Review. Vol 3 Nomor 1.

Devi Wahyuni, KKN-DR. 2020. Sebuah Usaha Pemberdayaan Masyarakat Ditengah Pandemi Covid-19. Kearsipan Pusat Pengabdian Kepada Masyarakat Universitas Islam Negeri Sunan Gunung Djati Bandung.

Evans, James R, William M. Lindsay. 2007. Pengantar Six Sigma An Introduction to Six Sigma \& Process Improvement. Jakarta: Salemba Empat.

Halim, A dkk. 2005. Manajemen Pesantren. Yogyakarta: Pustaka Pesantren. Hasbullah. 1996. Kapita Selekta Pendidikan Islam . Jakarta: Grafindo Persada.

Idris, Amiruddin. 2016. Pengantar Ekonomi Sumber Daya Manusia, Yogyakarta: deepublish.

Ikatan Akuntan Indonesia dan Bank Indonesia. 2017. Pedoman Akuntansi Pesantren, $1^{\text {st }}$ ed. Jakarta: Bank Indonesia.

Indarti, Nunuk. 2020. Pemberdayaan Industri Kecil dan Menengah Melalui Capacity Building pada Industri Mebel di Kota Pasuruan. Surabaya: Lembaga Academic \& Research Institute.

Ishomuddin, dkk. 2016. Pembangunan Sosial Dalam Menghadapi Masyarakat Ekonomi Asean. Pamekasan: Duta media Publishing.

Khoirur Rozaq. 2016. "Tantangan Pesantren dalam Menghadapi Asean Economic Community” Tebuireng, Edisi 43, Maret-April.

M., Hadfield, Chapman, C., Curryer, I., \& Barrett, P. 2004. Building Capacity Developing Your School. Retrieved from http:// www.ncsl.org.uk (Akses 19 Februari 2021).

Made Saihu, Made. 2020. Manajemen Berbasis Sekolah, Madrasah, dan Pesantren. Tanggerang: Yapin An-Namiyah.

Prasetyo, Aries Heru. 2010. Sukses Mengelola Kenangan Usaha Mikro Kecil Menengah. Jakarta: PT Elex Media Komputindo.

Riyanto, WH, Achmad Mohyi. 2020. Metodologi Penelitian Ekonomi. Malang: UMMPress. 
Saleh, Muhammad Yusuf, Milah Said. 2019. Konsep dan Strategi Pemasara. Makassar: CV Sah Media.

Sari, EK dan Advendi Simanunsong. 2007. Hukum Dalam Ekonomi. Jakarta: Grasindo.

Sofwan, Edi. 2020. Hukum Bisnis dan Regulasi. Banten: Desanta Muliavisitama.

Yuli Kurniati. Penguatan Kapasitas Kelembagaan Kelompok PEW Untuk Pengembangan Ekonomi Lokal Kota Yogyakarta. Jurnal Maksipreneur. Vol. III, No. 1. 